\title{
Evaluation of Berhane Hewan: A Program To Delay Child Marriage in Rural Ethiopia
}

By Annabel S. Erulkar and Eunice Muthengi

Annabel S. Erulkar is country director and senior associate, Population Council, Addis Ababa, Ethiopia. Eunice Muthengi is a doctoral candidate at the University of California, Los Angeles, School of Public Health, Los Angeles, CA, USA.
CONTEXT: Early marriage limits girls'opportunities and compromises their health, yet in Sub-Saharan Africa many girls are married before the age of 18, and few programs have sought to increase the age at marriage on the continent.

METHODS: Berhane Hewan was a two-year pilot project conducted in 2004-2006 that aimed to reduce the prevalence of child marriage in rural Ethiopia, through a combination of group formation, support for girls to remain in school and community awareness. A quasi-experimental research design with baseline and endline surveys was used to measure changes in social and educational participation, marriage age, reproductive health knowledge and contraceptive use. Chi-square tests, proportional hazards models and logistic regressions were conducted to assess changes associated with the project.

RESULTS: The intervention was associated with considerable improvements in girls'school enrollment, age at marriage, reproductive health knowledge and contraceptive use. Particularly among girls aged 10-14, those exposed to the program were more likely than those in the control area to be in school at the endline survey (odds ratio, 3.0) and were less likely to have ever been married (0.1). However, among girls aged 15-19, those in the intervention area had an elevated likelihood of having gotten married by the endline (2.4). Sexually experienced girls exposed to the intervention had elevated odds at endline of having ever used contraceptives (2.9).

CONCLUSIONS: The success of the Berhane Hewan program, one of the first rigorously evaluated interventions to delay marriage in Sub-Saharan Africa, suggests that well-designed and effectively implemented programs can delay the earliest marriages until later adolescence.

International Perspectives on Sexual and Reproductive Health, 2009, 35(1):6-14
Child marriage, defined as marriage before the age of 18 , affects girls to a far greater extent than boys. Age at first marriage is generally increasing around the world, though in many parts of South Asia and Sub-Saharan Africa, a significant proportion of girls are still married before reaching their 18th birthday. ${ }^{1,2}$

According to a number of international conventions, early marriage is considered a violation of human rights and effectively ends girls' opportunities for schooling, skills acquisition and personal development. ${ }^{3}$ Generally, girls in Sub-Saharan Africa and South Asia who are married early have less education and fewer opportunities, and the practice often forces a girl to reside in her husband's household, where she has low status and little power. After marriage, girls' confinement and isolation increase, likely due to greater domestic duties and control by husbands and senior household members. ${ }^{4}$ Marriage also marks the beginning of frequent and unprotected sexual activity, often leading to an early and risky first birth. ${ }^{3,4}$ Moreover, the younger a girl is when she marries, the greater the age difference with her partner, which further compromises her status and negotiating power within her marital home. ${ }^{5}$

In many settings, marriage also represents an increased risk of HIV infection. A study in Kenya and Zambia using biological markers and behavioral data found that married adolescent girls had rates of HIV that were 50\% higher than those of girls who were unmarried and sexually active; these elevated rates of infection were associated with more frequent intercourse, virtually no condom use and older partners who were more likely to be HIV-positive. ${ }^{6,7}$ Similarly, a study of more than 1,800 adolescent girls in Zimbabwe found that the odds of being HIV-positive for married girls were twice those for unmarried, sexually active girls. ${ }^{8}$

\section{BACKGROUND}

Ethiopia has one of the highest rates of early marriage in Sub-Saharan Africa: Nineteen percent of Ethiopian girls are married before their 15 th birthday. ${ }^{9}$ Nationally, the mean age at first marriage among Ethiopian women aged 25-49 is 16.1 , and 23.8 for men aged $25-59 .{ }^{10}$ However, national figures mask considerable differences in levels of early marriage by region. The Amhara region in northern Ethiopia is the second largest region in the country and has an estimated population of 19 million. In this region, $50 \%$ of girls are married by age 15 and $80 \%$ are married by age $18 .{ }^{11}$ On average, married girls in Ethiopia are nine years younger than their spouses. ${ }^{12}$

The forms of marriage practiced in Ethiopia vary greatly. Most marriages are arranged by parents, particularly among highland agriculturalists such as the Amhara. ${ }^{13,14}$ 
Normally, the prospective groom's family appoints an elder to conduct negotiations with the girl's family. After an agreement is reached, gifts are exchanged between families, with the balance of exchange favoring the girl's family. In cases of child marriage, arrangements are made until the child-bride can independently manage a household; this could include the girl living with the boy's parents or making periodic visits to the boy's family. ${ }^{15}$ Among the Amhara and other groups in Ethiopia, girls are traditionally supposed to be married before or at the time of puberty. ${ }^{14,16}$

Most early marriages do not involve the consent of the bride. A study among adolescents in Amhara found that only $15 \%$ of married girls had consented to be married, with younger brides being less likely to have given consent. ${ }^{16}$ Three percent of girls married before age 10 agreed to the marriage, compared with $42 \%$ of girls married between the ages of 16 and 19. Furthermore, $81 \%$ of married girls aged 10-19 in the sample reported that their first sexual intercourse had occurred against their will. ${ }^{16}$ Early marriage frequently leads to early divorce: The Amhara region has one of the highest rates of divorce in the world, with early marriage being a predictor of divorce. ${ }^{14}$

The legal marriage age in Ethiopia is 18 for both girls and boys, and the Ethiopian constitution states that "marriage shall be entered into only with the free and full consent of the intending spouses." 17 However, laws governing marriage are not enforced. The drivers of early marriage in Ethiopia have been described as a combination of cultural, social and economic factors. ${ }^{15}$ Marriage builds alliances between families and contributes to the status of parents. If a girl's family is poor, marriage relieves the economic cost of raising and feeding her, and provides some economic reward through the bride-price that they receive. Many rural Ethiopians believe that a girl who is not married by late adolescence represents a failure and disgrace to the family. In particular, the status of the girl's father is compromised, and he is considered a failure when his daughter remains unmarried into her late teens. ${ }^{15}$

\section{Programs to Delay Marriage}

Delaying marriage gives a girl the opportunity to complete schooling, explore positive livelihood choices and develop more fully as an individual in her own right. Few programs in Sub-Saharan Africa have focused on increasing marriage age, with even fewer including a rigorous evaluation framework. Indeed, interventions designed to increase the age at marriage have been largely confined to Asia. ${ }^{2}$ For example, in India, programs in several states provide families with economic incentives to delay the marriage of a girl, with larger incentives given if the girl remains unmarried until the legal age of $18 .^{2,3}$ A program in Nepal, one of whose stated goals was to raise the age of marriage, combined several approaches, including peer education, adult education, youth clubs and public theater. Evaluation of this program suggested that marriage age did increase in the urban study area, but not at the rural site; ${ }^{18}$ however, the descriptive analysis was insufficient to establish conclusively that the program had made a difference. In Bangladesh, a scholarship scheme for secondary-level female students was established that included a monthly stipend and agreement by participating parents that they would not marry off their daughters before the age of $18 .{ }^{19}$ An evaluation found that $36 \%$ of girls aged $11-19$ had married prior to the beginning of the project, compared with $32 \%$ after three years of program implementation.

\section{The Berhane Hewan Program}

Berhane Hewan ("Light for Eve" in Amharic), a program of the Ethiopia Ministry of Youth and Sport and the Amhara Regional Bureau of Youth and Sport, targets married and unmarried girls aged 10-19. Its overall goal is to establish appropriate and effective mechanisms to protect girls at risk of forced early marriage and support adolescent girls who are already married. Specific objectives include the creation of safe social spaces for the most vulnerable and isolated girls to meet same-sex friends and interact with caring adults; a reduction in the prevalence of childhood marriage among adolescent girls; and an increase in the use of reproductive health services among sexually experienced girls. The Berhane Hewan program includes three components: group formation by adult female mentors; support for girls to remain in school (including an economic incentive), and participation in nonformal education (e.g., basic literacy and numeracy) and livelihood training for out-of-school girls; and "community conversations," to engage the community in discussion of key issues, such as early marriage, and in collective problem solving.

Project components were designed based on formative research and discussions with community members and key stakeholders. For example, early discussions with community members from the Amhara region revealed that economic motivations were one of the drivers of early marriage, and interest in establishing an incentive to delay marriage arose from the community itself. In addition, there was high demand among adolescents in the project area for educational opportunities, which were seen as protective against early, arranged marriage. This pilot project was conducted in Mosebo, a rural village in the Amhara region, between 2004 and 2006.

- Recruitment. In the initial stage of the intervention, four female mentors were recruited from Mosebo, following announcements by local leaders regarding the positions. Mentors were leaders in the community and all had at least a 10th-grade education; several had experience in providing nonformal education in their community. They received five days of training, which covered topics such as the provision of nonformal education and reproductive health, HIV and AIDS education, as well as group facilitation techniques. Following training, mentors went door to door in Mosebo to identify eligible girls and to sensitize the community regarding the Berhane Hewan project. All girls aged 10-19 (married or unmarried) were eligible and were invited to participate in the project.

- Participation in girls' groups and support to remain in 
school. Participating girls had three options for involvement in the program. Girls who were still in school were encouraged to continue their education and were given school materials, such as exercise books, pens and pencils. Out-of-school girls who wanted to return to formal schooling were encouraged to do so and were given the same materials. Girls in these groups received about 36 birr (US\$4) in school materials over the course of a year. Other out-ofschool girls, as well as those who had never attended school, were organized into approximately 15 married and unmarried groups (of 15-20 girls each) that met with mentors. Because of time constraints, married groups met once a week, generally on Sundays, and unmarried groups met five times per week; all meetings were held in community halls or other public facilities. Nonformal education was given at each session, using the Ethiopia Ministry of Education curriculum, which includes basic literacy and numeracy lessons. Girls also learned livelihood skills, such as agricultural techniques, poultry rearing and construction of household items (e.g., mud seats, household partitions). Young women who asked about family planning and other reproductive health services were referred to the health center in a nearby regional town, Adet. (Family planning is free at government facilities, and the cost of a clinic card-20 birr, about US\$2.20-was supported by the project.)

After eligible girls were invited to participate, their parents or guardians were asked for permission. Both participants and parents were required to sign the program registration form. The parents of unmarried girls agreed that their daughters would not be married during the two-year program; they also agreed to allow them to attend the program meetings. Parents were promised that if they did not arrange to marry their daughters during this period, and their daughters attended at least $80 \%$ of the group sessions, a goat would be presented jointly to the girl and her family at the end of the program. At graduation, goats were worth about 180 birr (US\$20).

- Community conversations. Community conversation is a technique developed in Ethiopia that uses participatory community dialogue to explore problems and jointly devise solutions. ${ }^{20}$ Neighborhood meetings were held every two weeks at five sites in Mosebo, generally on Sundays or public holidays. Meetings included about 70 community members at each site; participants were selected from a range of backgrounds, regardless of age, sex or socioeconomic status. Four trained facilitators led discussions on early marriage, other harmful traditional practices, and matters affecting young women and girls. After several months of discussion, participants decided on specific collective actions, such as not to marry off their daughters early or not to circumcise them. Once a collective decision was reached, a subset of the group formed a committee, which in turn attempted to influence other community members to adopt the same resolution. The participatory nature of the meetings and stepwise progression of collective problem solving encouraged high levels of participation.

The main aim of this study was to analyze the impact of the Berhane Hewan project by assessing improvements in Mosebo participants' educational attainment, reproductive health knowledge, contraceptive use and age at first marriage.

\section{METHODS \\ Data Collection}

A baseline survey was conducted in early 2004 in the village of Mosebo and two other villages in Yilimana Densa district; because the program did not take place in the last two villages, these data were excluded from the analysis. Enamirt village in Mecha district-selected because it has a socioeconomic profile similar to that of Mosebo-served as a control village. Shortly after completion of the baseline survey in Mosebo and Enamirt, implementation of the Berhane Hewan program began in Mosebo. An endline survey was conducted in 2006 in both intervention and control villages.

Similar sample selection and data collection techniques were used for the baseline and endline surveys. All households in the study areas were listed, and demographic information on all household members was collected. Only households with a male or female adolescent aged 10-19 were eligible at baseline; for the endline survey, only households with a female adolescent were included. To assess the impact of the program on Mosebo girls, the baseline data for boys were dropped from the analysis. The number of adolescents selected from each village was proportionate to the size of the population. For households with more than one eligible adolescent, a Kish grid was used to select just one. ${ }^{21}$

Local interviewers recruited from the study areas administered the surveys; minimum qualifications included prior interviewing experience and a secondary school education. The program used interviewers who were relatively young (20-28) to make adolescents more comfortable and responsive. Interviewers received one day of training prior to the initial household listing and an additional five days of training before conducting surveys. During the training, they reviewed each item on the survey and engaged in one-on-one and group practice interviews. Once data collection began, they made up to three attempts to locate and interview selected adolescents. Because of the sensitive nature of the survey topics, adolescents were interviewed by interviewers of the same gender. The interviews generally took place at the respondent's household, during which interviewers ensured auditory privacy.

The survey instrument was largely closed-ended. Data were collected on participants' social and demographic characteristics, reproductive knowledge and history, ideal age at marriage and discussion of reproductive health issues. The baseline and endline surveys were nearly identical; the endline questionnaire also included questions on exposure to the various components of the intervention. The questionnaire was translated into Amharic and backtranslated into English to ensure accuracy. Completed questionnaires were checked by supervisors for data quality and completeness; data were entered into Epi Info and later converted to SPSS for analysis. 


\section{Measures}

At both baseline and endline surveys, respondents were asked if they had ever attended school and if they were currently attending school. They were also asked how many years of schooling they had received, and how well they could read (possible responses were easily, with difficulty and cannot read). Marital status was determined by asking if they had ever been married; the follow-up question, "Have you ever been married but later divorced?" was intended to minimize underreporting of marriage by formerly married young women. To determine whether the marriage of girls diminished during the project period, we constructed a variable to reflect recent marriages; by comparing a respondent's current age and age at first marriage, we determined whether she had gotten married in the prior year. We then compared the proportions of girls married in the year prior to both the baseline and the endline surveys; the latter marriages occurred during the period in which the Berhane Hewan program was being implemented in Mosebo. Respondents were also asked about previous pregnancies and births, and whether they lived with their parents.

Household socioeconomic status was measured using a list of 15 household amenities and assets, derived from the Ethiopia Demographic and Health Survey. A socioeconomic index was then created based on the number of items identified by each respondent: Poorer households were defined as those having five or fewer items, and wealthier households as those having six or more. A continuous socioeconomic status variable was used in the multivariate analyses.

In addition, respondents were asked about their awareness of contraceptive methods, their knowledge of STIs (e.g., whether they can tell if they or a man has an STI, and if a healthy-looking person can be HIV-positive) and whether they had discussed various reproductive health topics in the last year with their closest friends (e.g., HIV and AIDS, family planning methods and whether they had problems in their marriage). Furthermore, sexually experienced respondents were asked if they had ever used a contraceptive; the list of methods was read one by one as a probe.

To determine whether respondents had added to their friendship networks over the study period, they were asked if they had made new friends in the last year and had best friends outside of their families. Together with the school status indicators, these measures were used to assess whether the program had achieved the objective of increasing girls' access to safe social spaces. Finally, exposure to the program was measured by asking respondents which program activities they engaged in and which community conversations they attended.

\section{Analysis}

The analysis of respondents' social and demographic characteristics was based on the unweighted sample; all other analyses were adjusted for the number of eligible females in the household to compensate for unequal probabilities of selection, and weighted numbers are reported. Results for project exposure were based on girls living in Mosebo at endline, and all other results were based on girls in both project and control areas; analysis of contraceptive use included only girls who were sexually experienced. Variation in Ns among the different analyses is due to missing data for some measures.

Because events and transitions may occur at different times for younger versus older adolescents, analysis was stratified by age-group. For categorical variables, Pearson's chi-square test was used to assess differences between project and control groups for each survey period. Logistic regression or proportional hazards models were used to assess associations between respondents' characteristics and their school status, marital status and contraceptive use at both baseline and endline surveys; analyses controlled for age, socioeconomic status and project participation, as well as for marital status and years of schooling where applicable. In particular, we wanted to determine whether exposure to the intervention program was associated with positive outcomes.

\begin{tabular}{|c|c|c|c|c|}
\hline \multirow[t]{2}{*}{ Characteristic } & \multicolumn{2}{|l|}{ Baseline } & \multicolumn{2}{|l|}{ Endline } \\
\hline & $\begin{array}{l}\text { Project } \\
(\mathrm{N}=188)\end{array}$ & $\begin{array}{l}\text { Control } \\
(\mathrm{N}=272)\end{array}$ & $\begin{array}{l}\text { Project } \\
(\mathrm{N}=462)\end{array}$ & $\begin{array}{l}\text { Control } \\
(\mathrm{N}=464)\end{array}$ \\
\hline \multicolumn{5}{|l|}{ Age } \\
\hline $10-14$ & 56.9 & 49.4 & 54.1 & 53.2 \\
\hline $15-19$ & 43.1 & 50.6 & 45.9 & 46.8 \\
\hline \multicolumn{5}{|l|}{ School status } \\
\hline In school & 52.7 & 48.2 & 71.2 & 68.8 \\
\hline Out of school & 47.3 & 51.8 & 28.8 & 31.2 \\
\hline \multicolumn{5}{|l|}{ Yrs. of schooling } \\
\hline 0 & 43.9 & 44.9 & $23.5^{* * *}$ & 26.2 \\
\hline $1-4$ & 38.5 & 39.3 & 49.8 & 36.0 \\
\hline $5-8$ & 16.6 & 15.1 & 20.2 & 32.3 \\
\hline$\geq 9$ & 1.0 & 0.7 & 6.5 & 5.4 \\
\hline \multicolumn{5}{|l|}{ Marital status } \\
\hline Never-married & $71.8^{*}$ & 59.9 & 76.0 & 74.8 \\
\hline Married & 23.4 & 31.6 & 21.3 & 20.2 \\
\hline \multicolumn{5}{|l|}{ Divorced/widowed/ } \\
\hline separated & 4.8 & 8.5 & 2.7 & 5.0 \\
\hline \multicolumn{5}{|l|}{ Parity } \\
\hline 0 & 92.4 & 78.3 & 85.2 & 85.8 \\
\hline$\geq 1$ & $7.6^{* * *}$ & 21.7 & 14.8 & 14.2 \\
\hline \multicolumn{5}{|l|}{ Lives with parents } \\
\hline Both & 41.7 & 40.7 & 46.7 & 48.6 \\
\hline Mother only & 18.7 & 16.8 & 21.3 & 19.2 \\
\hline Father only & 7.0 & 6.3 & 4.8 & 6.3 \\
\hline Neither & 32.6 & 36.2 & 27.2 & 25.9 \\
\hline \multicolumn{5}{|c|}{ Household socioeconomic index } \\
\hline Poorer ( $0-5$ items) & $77.0^{* *}$ & 62.9 & $57.0^{* * *}$ & 24.9 \\
\hline Wealthier (6-15 items) & 23.0 & 37.1 & 43.0 & 75.1 \\
\hline Total & 100.0 & 100.0 & 100.0 & 100.0 \\
\hline
\end{tabular}

${ }^{*} \mathrm{p}<.05 .{ }^{* *} \mathrm{p}<.01 .{ }^{* * *} \mathrm{p}<.001$. Notes: Percentages based on unweighted Ns. Significance testing assessed differences between project and control groups at baseline and at endline. 


\begin{tabular}{|c|c|c|c|}
\hline Component & $\begin{array}{l}\text { All } \\
(\mathrm{N}=668)\end{array}$ & $\begin{array}{l}10-14 \\
(\mathrm{~N}=367)\end{array}$ & $\begin{array}{l}15-19 \\
(\mathrm{~N}=301)\end{array}$ \\
\hline \multicolumn{4}{|l|}{ Participated in group $* * *$} \\
\hline Formal schooling support & 52.1 & 65.4 & 37.2 \\
\hline Unmarried group & 22.9 & 22.3 & 23.5 \\
\hline Married group & 10.2 & 0.0 & 22.4 \\
\hline Did not participate & 14.8 & 12.3 & 16.9 \\
\hline Total & 100.0 & 100.0 & 100.0 \\
\hline \multicolumn{4}{|c|}{ Attended a community conversation } \\
\hline General community matters & 41.0 & 36.0 & $47.0^{* *}$ \\
\hline Early marriage & 72.0 & 72.0 & 72.5 \\
\hline HIV/AIDS & 70.3 & 68.7 & 72.8 \\
\hline Family planning & 54.9 & 48.5 & $62.8^{* * *}$ \\
\hline Safe motherhood & 43.5 & 32.4 & $56.4^{* * *}$ \\
\hline Did not attend & 26.9 & 26.7 & 27.3 \\
\hline
\end{tabular}

\section{RESULTS}

\section{Sample Characteristics}

A total of 460 respondents completed the baseline survey188 girls from Mosebo village, the intervention area, and 272 girls from the control village of Enamirt. Fewer respondents from the intervention area were included at baseline because the program did not take place in two other villages, as had been anticipated. The endline sample included 462 girls from Mosebo and 464 from Enamirt.

There were no significant differences between groups at baseline or endline regarding age, school status or living arrangements (Table 1, page 9). However, at baseline, a higher proportion of girls from the intervention site than of girls from the control site had never been married ( $72 \%$ vs. 60\%), and they were less likely to have children ( $8 \%$ vs. $22 \%$ ). At endline, girls in the control area were more likely than girls in the intervention area to have completed at least five years of schooling (38\% vs. 27\%). Regarding socioeconomic status, higher proportions of girls in the intervention area than of those in the control site fell into the poorer category at both baseline (77\% vs. $63 \%$ ) and endline (57\% vs. $25 \%$ ).

\section{Exposure to Berhane Hewan}

At the endline survey, 92\% of girls in Mosebo had heard of the Berhane Hewan project, whereas none of the girls in the control area had ever heard of it (not shown). About half of the girls in the intervention area received support to remain in school, one-fifth participated in a nonformal education group for unmarried girls and 10\% participated in a club for married girls (Table 2). Participation differed by age: Sixtyfive percent of girls aged 10-14 received formal schooling support and none participated in married girls' clubs, while $37 \%$ of girls aged 15-19 received schooling support and $22 \%$ participated in married girls' clubs. Nearly a quarter of girls in both age-groups joined groups for unmarried girls.

About three-fourths of girls attended at least one community conversation, the most attended being those on early marriage and HIV and AIDS (70-72\%). Older girls were more likely than younger girls to have attended meetings on community issues ( $47 \%$ vs. $36 \%$ ), family planning (63\% vs. $49 \%$ ) and safe motherhood (56\% vs. $32 \%$ ).

\section{Social Networks, Education and Marriage}

Berhane Hewan provided girls with opportunities to expand their social networks by participating in same-sex groups led by adult female mentors. At baseline, girls from Mosebo were less likely than those in the control area to have made new friends in the last year (4\% vs. 16\%; not shown) or to report a nonfamilial best friend (30\% vs. 48\%). At endline, neither of these indicators differed between groups, likely owing to the expanded social networks observed among Mosebo girls. Furthermore, the proportion of Mosebo girls who made new friends in the previous year increased from $4 \%$ at baseline to $18 \%$ at endline, while the

\begin{tabular}{|c|c|c|c|c|c|c|c|c|}
\hline \multirow[t]{3}{*}{ Characteristic } & \multicolumn{4}{|l|}{$10-14$} & \multicolumn{4}{|l|}{$15-19$} \\
\hline & \multicolumn{2}{|l|}{ Baseline } & \multicolumn{2}{|l|}{ Endline } & \multicolumn{2}{|l|}{ Baseline } & \multicolumn{2}{|l|}{ Endline } \\
\hline & $\begin{array}{l}\text { Project } \\
(\mathrm{N}=169)\end{array}$ & $\begin{array}{l}\text { Control } \\
(\mathrm{N}=209)\end{array}$ & $\begin{array}{l}\text { Project } \\
(\mathrm{N}=367)\end{array}$ & $\begin{array}{l}\text { Control } \\
(\mathrm{N}=348)\end{array}$ & $\begin{array}{l}\text { Project } \\
(\mathrm{N}=113)\end{array}$ & $\begin{array}{l}\text { Control } \\
(\mathrm{N}=205)\end{array}$ & $\begin{array}{l}\text { Project } \\
(\mathrm{N}=301)\end{array}$ & $\begin{array}{l}\text { Control } \\
(\mathrm{N}=273)\end{array}$ \\
\hline \multicolumn{9}{|l|}{ Education } \\
\hline Any & $70.8^{*}$ & 81.8 & 96.5 & 93.4 & 44.2 & 34.6 & 60.3 & 58.2 \\
\hline Currently in school & 69.6 & 77.5 & $95.9^{* *}$ & 89.0 & 38.4 & 27.3 & 48.5 & 54.2 \\
\hline Yrs. of schooling (mean) & 2.3 & 2.5 & $2.7^{* * *}$ & 3.7 & 2.9 & 1.7 & 3.5 & 4.0 \\
\hline \multicolumn{9}{|l|}{ Literacy† } \\
\hline Reads easily & $33.9 * * *$ & 31.6 & $40.3^{*}$ & 50.3 & 25.0 & 18.5 & 36.9 & 41.8 \\
\hline Reads with difficulty & 21.4 & 40.2 & 38.4 & 30.7 & 16.1 & 11.2 & 17.3 & 11.7 \\
\hline Cannot read & 44.6 & 28.2 & 21.3 & 19.0 & 58.9 & 70.2 & 45.8 & 46.5 \\
\hline \multicolumn{9}{|l|}{ Marital status } \\
\hline Ever-married & 9.5 & 13.9 & $1.6^{* * *}$ & 22.1 & 46.0 & 57.1 & $45.8^{* * *}$ & 29.7 \\
\hline Married in last yearł & 1.3 & 1.6 & $0.0 * * *$ & 4.8 & $8.6^{*}$ & 19.8 & 7.4 & 3.9 \\
\hline
\end{tabular}

${ }^{*} \mathrm{p}<.05 .{ }^{* *} \mathrm{p}<.01 .{ }^{* * * *} \mathrm{p}<.001$. Significance testing assessed differences between the percentage distributions for project and control groups at baseline and at endline. $¥$ Among respondents who had not yet married two years before the survey period. Notes: Percentages based on weighted Ns. Significance testing assessed differences between project and control groups at baseline and at endline. 
rate for girls in the control site remained stable (16\% and $15 \%$, respectively). At the endline survey, similar proportions of girls from the intervention and control sites reported a nonfamilial best friend (51\% and 54\%, respectively).

Among those aged $10-14$ at baseline, $71 \%$ of girls in the intervention site and $82 \%$ of girls in the control site had ever attended school (Table 3); by the endline survey, the proportions at the two sites did not differ significantly ( $97 \%$ and $93 \%$, respectively). In contrast, similar proportions of younger girls at the intervention and control sites were in school at baseline (70-78\%), but by endline a significantly higher proportion of girls in Mosebo were in school (96\% vs. 89\%). Overall, girls from the control village reported more years of schooling at endline than did girls from Mosebo (3.7 vs. 2.7). Regarding literacy, $45 \%$ of Mosebo girls aged $10-14$ and $28 \%$ of those in the control group could not read at baseline, but these proportions were similar at the endline survey (21\% and 19\%, respectively). Among older adolescents, changes in school status were less clear; enrollment rose between surveys, but no significant differences were found between study sites.

Though most girls in rural Ethiopia do not decide when they will get married, the surveys asked respondents at what age they would like to get married. At baseline, a higher proportion of Mosebo girls than of girls in the control site said they would like to get married before they turned 18 (11\% vs. $5 \%$ ); at the endline survey, only 3\% of girls from either site said they wanted to be married by this age (not shown).

Among girls aged 10-14 at baseline at the intervention and control sites, similar proportions had ever been married ( $10 \%$ and $14 \%$, respectively), but by the endline survey, the proportion of ever-married girls at the intervention site had dropped to $2 \%$, while the proportion of those at the control site had risen to $22 \%$ (Table 3 ). When the sample was restricted to girls who had not been married two years before the survey periods, a similar pattern was observed: The proportions of girls who got married in the year prior to baseline were nearly the same (1\%-2\%), but at endline none of the Mosebo girls had gotten married in the previous year, whereas 5\% of the controls had done so.

Among girls aged 15-19, similar proportions of those in the intervention and control groups had been married at baseline ( $46 \%$ and $57 \%$, respectively), while by the endline survey, a higher percentage of Mosebo girls than of girls in the control site had ever been married ( $46 \%$ vs. $30 \%$ ). It is notable, however, that the proportion of ever-married girls in Mosebo did not change over the study period. The percentage of girls who had gotten married in the year before the baseline survey was significantly lower in the intervention than the control group ( $9 \%$ vs. $20 \%$ ), yet the proportions who got married in the year prior to the endline survey were similar ( $7 \%$ and $4 \%$, respectively).

\section{Reproductive Health}

Girls at the intervention site were significantly more likely than girls at the control site to know about oral contraceptives at both baseline ( $86 \%$ vs. $77 \%$ ) and endline surveys
TABLE 4. Percentage of girls reporting awareness of methods, knowledge of STIs, discussion of reproductive health topics and contraceptive use, by project and control group, according to time of survey

\begin{tabular}{|c|c|c|c|c|}
\hline \multirow[t]{2}{*}{ Characteristic } & \multicolumn{2}{|l|}{ Baseline } & \multicolumn{2}{|l|}{ Endline } \\
\hline & $\begin{array}{l}\text { Project } \\
(\mathrm{N}=281)\end{array}$ & $\begin{array}{l}\text { Control } \\
(\mathrm{N}=416)\end{array}$ & $\begin{array}{l}\text { Project } \\
(\mathrm{N}=677)\end{array}$ & $\begin{array}{l}\text { Control } \\
(\mathrm{N}=620)\end{array}$ \\
\hline \multicolumn{5}{|l|}{ Awareness of method } \\
\hline Pill & $86.2^{* *}$ & 77.2 & $91.1^{* *}$ & 86.3 \\
\hline Injectable & 85.5 & 82.9 & $90.7^{* *}$ & 85.5 \\
\hline Condom & $26.2^{* *}$ & 36.2 & $32.1^{* * *}$ & 16.2 \\
\hline None & 11.4 & 13.9 & 7.6 & 10.8 \\
\hline \multicolumn{5}{|l|}{ Knowledge of STIs } \\
\hline Cannot always tell if infected with an STI & $31.0^{*}$ & 38.8 & 29.1 & 31.3 \\
\hline Cannot always tell if a man has an STI & 35.6 & 41.1 & $60.9^{* * *}$ & 45.2 \\
\hline A healthy-looking person can be HIV-positive & $65.2^{* *}$ & 77.9 & $88.2^{* * * *}$ & 71.8 \\
\hline Most people don't get HIV from sharp objects & 24.1 & 23.8 & 34.4 & 32.4 \\
\hline There is no cure for HIV/AIDS & $53.4^{* *}$ & 64.9 & $88.5^{* * *}$ & 77.8 \\
\hline HIV can be transmitted through intercourse & $78.7^{*}$ & 84.7 & $92.9^{*}$ & 89.2 \\
\hline \multicolumn{5}{|l|}{ Discussed topic in last year with closest friends } \\
\hline HIV/AIDS & 30.1 & 34.9 & $79.4^{* * *}$ & 58.5 \\
\hline STIs & 28.0 & 28.6 & $50.1^{* * *}$ & 32.2 \\
\hline Family planning methods & $29.5^{*}$ & 37.7 & $58.1^{* * *}$ & 44.8 \\
\hline Condoms & $13.0^{*}$ & 21.4 & $24.3^{* *}$ & 18.1 \\
\hline Violence in community & $24.9^{* *}$ & 38.2 & $50.8^{* *}$ & 41.5 \\
\hline Problems in marriaget & 55.6 & 55.9 & $81.6^{* * *}$ & 23.5 \\
\hline Kind of spouse desired $\neq$ & 10.9 & 10.8 & $13.9^{* *}$ & 25.2 \\
\hline Ever-use of contraceptive§ & $(\mathrm{N}=58)$ & $(\mathrm{N}=119)$ & $(\mathrm{N}=143)$ & $(\mathrm{N}=145)$ \\
\hline Pill & 34.5 & 23.3 & 28.7 & 21.4 \\
\hline Injectable & 34.5 & 31.0 & $66.4^{* * *}$ & 42.1 \\
\hline Condom & 5.2 & 1.7 & 2.1 & 0.0 \\
\hline Ever used any method & 43.2 & 36.1 & $74.1^{* * *}$ & 44.8 \\
\hline
\end{tabular}

${ }^{*} \mathrm{p}<.05 .{ }^{* *} \mathrm{p}<.01 .{ }^{* * *} \mathrm{p}<.001$. †Among married respondents. $\ddagger$ Among unmarried respondents. §Among sexually experienced respondents. Notes: Percentages based on weighted Ns. Significance testing assessed differences between project and control groups at baseline and at endline.

(91\% vs. 86\%; Table 4). Although Mosebo girls reported lower awareness of condoms at baseline ( $26 \%$ vs. $36 \%$ ), they were more aware of both condoms (32\% vs. 16\%) and the injectable ( $91 \%$ vs. $86 \%$ ) at the end of the study. Regarding knowledge of STIs, girls at the intervention site were less knowledgeable than girls at the control site about four of the six STI items at baseline, whereas they were more knowledgeable about four of the items at endline.

Another goal of the intervention was to promote the discussion of reproductive health topics among participants and their friends. At baseline, girls in Mosebo were less likely than girls in the control site to talk to their closest friends about family planning, condoms and violence in their com-

\begin{tabular}{|c|c|c|c|c|}
\hline \multirow[t]{2}{*}{ Characteristic } & \multicolumn{2}{|l|}{$10-14$} & \multicolumn{2}{|l|}{$15-19$} \\
\hline & $\begin{array}{l}\text { Baseline } \\
(\mathrm{N}=377)\end{array}$ & $\begin{array}{l}\text { Endline } \\
(\mathrm{N}=709)\end{array}$ & $\begin{array}{l}\text { Baseline } \\
(\mathrm{N}=317)\end{array}$ & $\begin{array}{l}\text { Endline } \\
(\mathrm{N}=572)\end{array}$ \\
\hline Age & $1.29^{* *}$ & 0.94 & $0.53^{* * *}$ & $0.49 * * *$ \\
\hline $\begin{array}{l}\text { Household socioeconomic } \\
\text { index (range, } 0-15)\end{array}$ & $1.23^{* *}$ & 1.11 & $1.25^{*}$ & $1.12^{* *}$ \\
\hline $\begin{array}{l}\text { Ever-married } \\
\text { Site }\end{array}$ & $0.15^{* * *}$ & 0.65 & $0.04^{* * *}$ & $0.12^{* * *}$ \\
\hline Project & $0.57^{* *}$ & $2.99 * *$ & 1.75 & 1.35 \\
\hline Control (ref) & 1.00 & 1.00 & 1.00 & 1.00 \\
\hline
\end{tabular}

${ }^{*} \mathrm{p}<.05 .{ }^{* *} \mathrm{p}<.01 .{ }^{* * *} \mathrm{p}<.001$. Note: ref $=$ reference category. 
TABLE 6. Hazards ratios from proportional hazards analyses identifying associations between selected characteristics and girls' ever having been married, by age and time of survey

\begin{tabular}{|c|c|c|c|c|}
\hline \multirow[t]{2}{*}{ Characteristic } & \multicolumn{2}{|l|}{$10-14$} & \multicolumn{2}{|l|}{ |15-19 } \\
\hline & $\begin{array}{l}\text { Baseline } \\
(\mathrm{N}=374)\end{array}$ & $\begin{array}{l}\text { Endline } \\
(\mathrm{N}=699)\end{array}$ & $\begin{array}{l}\text { Baseline } \\
(\mathrm{N}=337)\end{array}$ & $\begin{array}{l}\text { Endline } \\
(\mathrm{N}=551)\end{array}$ \\
\hline Age & $1.31^{*}$ & $0.74^{* *}$ & 1.05 & 0.99 \\
\hline \multicolumn{5}{|l|}{ Household socioeconomic } \\
\hline index (range, $0-15$ ) & $1.25^{*}$ & 1.04 & $1.11^{*}$ & $1.20^{* * *}$ \\
\hline Yrs. of schooling & $0.76^{* *}$ & 1.02 & $0.67^{* * *}$ & $0.83^{* * *}$ \\
\hline \multicolumn{5}{|l|}{ Site } \\
\hline Project & 0.66 & $0.09 * * *$ & 0.87 & $2.41^{* * *}$ \\
\hline Control (ref) & 1.00 & 1.00 & 1.00 & 1.00 \\
\hline
\end{tabular}

munities. At the end of the study period, however, Mosebo girls were more likely to discuss these topics, as well as HIV and AIDS (79\% vs. $59 \%$ ), STIs (50\% vs. $32 \%$ ) and problems in their marriage ( $82 \%$ vs. $24 \%$ ); the only topic that girls in the control site were more likely to discuss was what kind of spouse they would like (25\% vs. 14\%, among unmarried girls). Between the baseline and endline surveys, the proportion of girls who discussed family planning methods rose from $30 \%$ to $58 \%$ among girls at the intervention site and from $38 \%$ to $45 \%$ among those at the control site.

Among sexually experienced girls (only two of whom had never married), there were no differences in contraceptive use between those at the intervention site and those at the control site at baseline. Thirty-five percent of girls at the intervention site reported having used the pill, another $35 \%$ had used the injectable and 5\% had used condoms; $43 \%$ had ever used any method. By the end of the study, higher proportions of girls at the intervention site than of those at the control site reported having ever used the injectable (66\% vs. $42 \%$ ) or any method (74\% vs. $45 \%$ ).

\section{Multivariate Analyses}

Weighted logistic regression analysis found that 10-14-yearolds in Mosebo were less likely than that age-group in the control area to be in school at baseline, while at endline they were more likely to be in school (odds ratios, 0.6 and 3.0, respectively; Table 5, page 11). Factors associated with in-

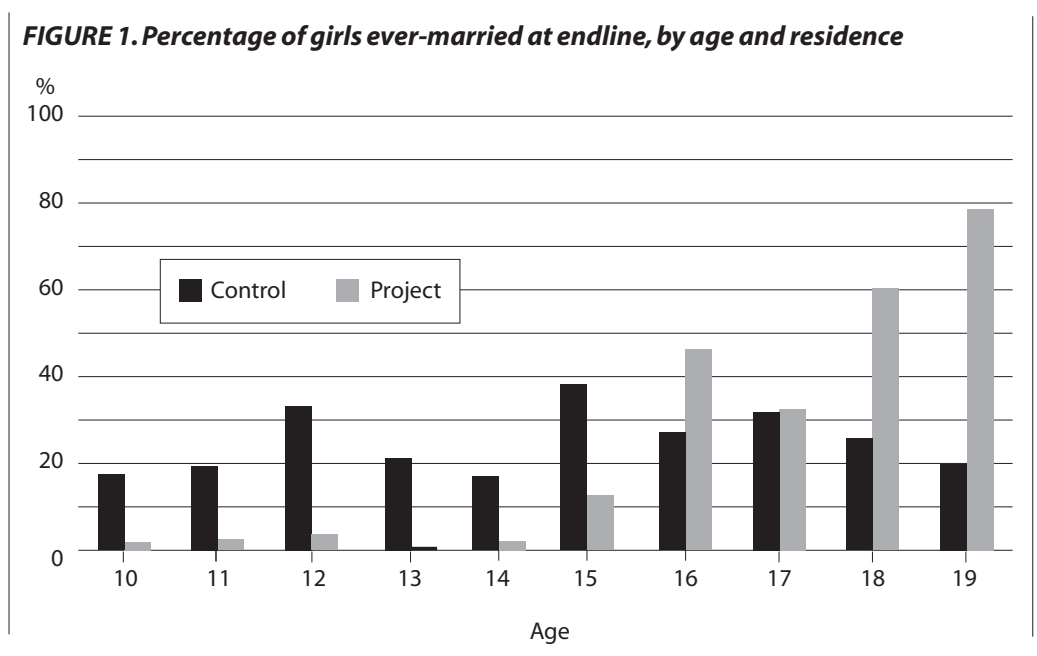

TABLE 7. Odds ratios from weighted logistic regression analyses identifying associations between selected characteristics and ever-use of contraceptives among sexually experienced girls, by time of survey

\begin{tabular}{lll} 
Characteristic & $\begin{array}{l}\text { Baseline } \\
(\mathrm{N}=175)\end{array}$ & $\begin{array}{l}\text { Endline } \\
(\mathrm{N}=285)\end{array}$ \\
\hline Age & $0.91 * * *$ & 1.01 \\
Household socioeconomic index (range, $0-15)$ & $1.22^{*}$ & 0.98 \\
Yrs. of schooling & $1.60^{*}$ & 0.94 \\
Site & & \\
$\quad$ Project & 1.33 & $2.88^{* *}$ \\
$\quad$ Control (ref) & 1.00 & 1.00 \\
\hline${ }^{* p}<.05 . *{ }^{*}<.01 . * * p<.001$. Note: ref=reference category. &
\end{tabular}

creased odds of being in school at baseline were older age and higher socioeconomic status (1.3 and 1.2, respectively); girls who had ever been married had lower odds of being enrolled than their unmarried counterparts (0.2). Among older girls, there was no difference in school status between intervention and control groups at either survey. At both baseline and endline, girls with higher socioeconomic status were more likely to be in school (1.3 and 1.1, respectively), whereas older girls and those who had ever been married were less likely to be currently enrolled (0.04-0.5).

Using a proportional hazards model, we found that for girls aged 10-14 at baseline, the likelihood of having ever been married increased with age and higher socio-economic status (hazards ratios, 1.3 for each) and decreased with years of education (0.8; Table 6). At endline, however, Mosebo girls were much less likely than girls at the control site to have gotten married (0.1), suggesting that the Berhane Hewan program may have helped delay marriage in this age-group.

For girls aged 15-19, this model found that at both surveys, ever being married was associated with higher socioeconomic status (hazards ratios, 1.1-1.2) and more schooling (0.7-0.8). At endline, however, girls in the intervention site were more likely than those in the control site to have ever been married (2.4). Paradoxically, while younger girls in the project area appeared to delay marriage, older girls seemed more likely to get married (Figure 1). In contrast, girls in the control area seemed to get married at a fairly constant rate across the age range, with many remaining unmarried even during later adolescence.

Logistic regression analysis found no significant differences in ever-use of contraceptives between the groups at baseline, although younger girls had lowered odds of such use (odds ratio, 0.9 ) and girls with higher socioeconomic status or more schooling had elevated odds of use (1.2 and 1.6, respectively; Table 7). By the end of the intervention, however, Mosebo girls were more likely than girls from the control village to have used contraceptives (2.9).

\section{DISCUSSION}

The Berhane Hewan program was developed to address the high level of child marriage in the rural Amhara region of Ethiopia; it is one of the first programs of its kind in SubSaharan Africa to incorporate an evaluation mechanism. 
The intervention used a combination of participation in girls' groups to combat the isolation of adolescents; promotion of school attendance (for both formal and nonformal education); incentives for school attendance and delaying marriage; and participatory community conversations on early marriage, other harmful traditional practices and reproductive health. The program design acknowledged that the reasons for child marriage are complex and that interventions should simultaneously address girls' low status and social isolation, educational and livelihood opportunities, economic drivers of the practice, and societal norms and pressures.

Improvements associated with the program were seen in all outcomes of interest, including friendship networks, school attendance, age at marriage, reproductive health knowledge and communication, and contraceptive use. For example, although Mosebo girls had fewer friends and smaller social networks at baseline, their networks had increased by the end of the intervention, as had communication on topics such as reproductive health, family planning and family issues. In addition, Mosebo girls aged 10-14 experienced significant improvement in school enrollment over the intervention period, although the increased enrollment was too recent to be reflected in their mean years of schooling, and some of it might be attributed to a general intensification of efforts in Ethiopia to promote education and progress toward millennium development goals. Furthermore, over the study period, girls' marriage arrangements seemed to be delayed to later adolescence; thus, although marriage before age 18 was still common in the area, the youngest girls were less affected by the practice than they had been before the intervention was conducted. In effect, girls were given a few critical extra years in which to expand their social networks, attend school, learn more skills and develop as individuals.

Another notable improvement was increased use of contraceptives in the intervention area; three-fourths of sexually experienced girls in Mosebo had used a method by the end of the study. Delaying the age at first birth reduces adverse birth outcomes-including maternal mortality, which is high in Ethiopia-and morbidity (e.g., fistula), which is also common.

This study has several limitations. The high levels of exposure to all project components made it difficult to ascertain which activities may have been more influential in promoting the intended changes among unmarried girls. In addition, the quasi-experimental design did not allow us to account for girls who may have migrated out of the research areas, or for girls who were married to boys or men in other locations or who migrated to escape early forced marriage. However, this would be a shortcoming of many evaluations of similar research design.

In Ethiopia, sexual initiation still largely occurs within marriage, especially among rural populations and young women. ${ }^{22,23}$ That so few girls in rural Ethiopia experience sex before marriage reflects that marriage is a key driver of sexual initiation and early first birth; conversely, delaying marriage may delay sexual debut and pregnancy. In settings such as the rural Amhara region, traditional beliefs about the appropriate age for girls' marriage conflict with girls' continuing education. Moreover, public health officials generally believe that girls in early adolescence are developmentally and physiologically too young to make marital, sexual and reproductive transitions. ${ }^{24}$ Berhane Hewan simultaneously addresses the economic and social factors that promote early marriage, and provides girls with alternative pathways through educational development. Such approaches have tremendous potential in settings where large numbers of girls are married before age 15 and do not attend school. In Sub-Saharan Africa, these settings include countries such as Niger and Mali and northern Nigeria. Berhane Hewan demonstrates that the incentives and traditions that support the earliest marriages can be changed in a relatively short period by altering local opportunity structures and addressing motivations for arranging marriages for young girls.

\section{REFERENCES}

1. United Nations Children's Fund (UNICEF), Early Marriage: Child Spouses, Florence, Italy: UNICEF, 2001.

2. Lloyd CB, ed., Growing Up Global: The Changing Transitions to Adulthood in Developing Countries, Washington, DC: National Academies Press, 2005.

3. Mensch B, Bruce J and Greene M, The Uncharted Passage: Girls' Adolescence in the Developing World, New York: Population Council, 1998.

4. Haberland N et al., Early marriage and adolescent girls, YouthLens on Reproductive Health and HIV/AIDS, Research Triangle Park, NC, USA: YouthNet, 2005, No. 15.

5. United Nations Population Fund (UNFPA), Child marriage fact sheet, New York: UNFPA, 2005.

6. Clark S, Early marriage and HIV risks in Sub-Saharan Africa, Studies in Family Planning, 2004, 35(3):149-160.

7. Glynn JR et al., Why do young women have a much higher prevalence of HIV than young men? a study in Kisumu, Kenya and Ndola, Zambia, AIDS, 2001, 15(Suppl. 4):S51-S60.

8. Gavin L et al., Factors associated with HIV infection in adolescent females in Zimbabwe, Journal of Adolescent Health, 2006, 39(4):596607.

9. Clark S, Bruce J and Dude A, Protecting young women from HIV/AIDS: the case against child and adolescent marriage, International Family Planning Perspectives, 2006, 32(2):79-88.

10. Central Statistical Agency and ORC Macro, Ethiopia Demographic and Health Survey, 2005, Addis Ababa, Ethiopia: Central Statistical Agency; and Calverton, MD, USA: ORC Macro, 2006.

11. Population Council, Child marriage briefing: Ethiopia, briefing sheet, New York: Population Council, 2004.

12. Bruce J and Clark S, The Implications of Early Marriage for HIV/AIDS Policy, New York: Population Council, 2004.

13. National Committee on Traditional Practices of Ethiopia (NCTPE), Old Beyond Imaginings: Ethiopia, Harmful Traditional Practices, Addis Ababa, Ethiopia: NCTPE, 2003.

14. Tilson D and Larsen U, Divorce in Ethiopia: the impact of early marriage and childlessness, Journal of Biosocial Science, 2000, 32(3): $355-372$

15. Pathfinder International, Report on the Causes and Consequences of Early Marriage in Amhara Region, Addis Ababa, Ethiopia: Pathfinder International, 2006. 
16. Erulkar A et al., The Experience of Adolescence in Rural Amhara Region, Ethiopia, Accra, Ghana: Population Council, 2004.

17. Federal Democratic Republic of Ethiopia Const, Art 34, Marital, personal and family rights, <http://www.ethiopiafirst.com/ Election2008/Constitution.pdf>, accessed Feb. 20, 2009

18. Mathur S, Mehta M and Malhotra A, Youth Reproductive Health in Nepal: Is Participation the Answer? New York: EngenderHealth; and Washington, DC: International Center for Research on Women, 2004.

19. Arends-Kuenning $\mathrm{M}$ and Amin S, The effects of schooling incentive programs on household resource allocation in Bangladesh, Policy Research Division Working Papers, New York: Population Council, 2000, No. 133

20. Gebre A and Admassie Y, Community Conversations on HIV/AIDS Pilot Projects in Alaba and Yabello: Assessment of the Methodology, Addis Ababa, Ethiopia: United Nations Development Programme, 2005.

21. Kish L, Survey Sampling, New York: Wiley, 1965.

22. Govindasamy P, Kidanu A and Banteyerga H, Youth Reproductive Health in Ethiopia, Calverton, MD, USA: ORC Macro, 2002.

23. Molla M, Berhane Y and Lindtjorn B, Traditional values of virginity and sexual behaviour in rural Ethiopian youth: results from a crosssectional study, BMC Public Health, 2008, Vol. 8, Art. 9, <http://www. biomedcentral.com/1471-2458/8/9>, accessed Feb. 20, 2009.

24. Dixon-Mueller R, How young is 'too young'? comparative perspectives on adolescent sexual, marital, and reproductive transitions, Studies in Family Planning, 2008, 39(4):247-262.

\section{RESUMEN}

Contexto: El matrimonio temprano limita las oportunidades de las niñas y compromete su salud; a pesar de ello, en África Subsahariana muchas niñas contraen matrimonio antes de los 18 años; $y$ son pocos los programas que han buscado aumentar la edad del matrimonio en ese continente.

Métodos: "Berhane Hewan" fue un proyecto piloto conducido entre 2004 y 2006, que tuvo el propósito de reducir la prevalencia del matrimonio infantil en el medio rural de Etiopía, a través de una combinación de formación de grupos, apoyo a las niñas para que siguieran asistiendo a la escuela y toma de conciencia comunitaria. Se utilizó un diseño de investigación cuasi-experimental con encuestas de línea de base y linea final para medir los cambios en la participación social y educativa, la edad al contraer matrimonio, el conocimiento sobre salud reproductiva y el uso de anticonceptivos. Se condujo una serie de pruebas chi-cuadrada, modelos de riesgo proporcional y regresiones logísticas para evaluar los cambios asociados con el proyecto.

Resultados: La intervención se asoció con considerables mejoras en la matriculación de niñas en la escuela, la edad al contraer matrimonio, el conocimiento sobre salud reproductiva y el uso de anticonceptivos. En particular, en niñas de 10-14 años de edad, aquellas expuestas al programa tuvieron más probabilidad que las del área de control de permanecer en la escuela al final de la encuesta (razón de momios, 3.0); y tuvieron menos probabilidad de haber estado casadas (0.1). Sin embargo, en niñas de 15-19 años de edad, las del área de intervención tuvieron una elevada probabilidad de haber contraído matrimonio en el momento de la encuesta de línea final (2.4). Las niñas con experiencia sexual que estuvieron expuestas a la intervención tuvieron, al momento de la encuesta de línea final, elevadas probabilidades de haber usado alguna vez anticonceptivos (2.9).

Conclusiones: El éxito del programa Berhane Hewan, una de las primeras intervenciones para retrasar el matrimonio en África Subsahariana que había sido sometido a una evaluación rigurosa, sugiere que los programas bien diseñados e implementados de manera efectiva pueden retrasar los matrimonios más tempranos hasta la adolescencia tardía.

\section{RÉSUMÉ}

Contexte: Le mariage précoce limite les horizons ouverts aux filles et compromet leur santé. En Afrique subsaharienne, pourtant, beaucoup sont mariées avant l'âge de 18 ans et peu de programmes cherchent à accroître l'âge du mariage sur le continent. Méthodes: Sur une période de deux ans (2004-2006), le projet pilote Berhane Hewan a cherché à réduire la prévalence des mariages d'enfants en Éthiopie rurale, à travers une combinaison de formation de groupe, soutien de la scolarisation prolongée des filles et sensibilisation des communautés. Un plan de recherche quasi-expérimental avec enquêtes de référence et de fin d'étude a servi à mesurer les changements en termes de participation sociale et scolaire, âge au mariage, sensibilisation à la santé génésique et pratique contraceptive. Les changements associés au projet ont été évalués par tests chi carré, modèles de risques proportionnels et régressions logistiques.

Résultats: L'intervention s'est révélée associée à de considérables améliorations au niveau de la scolarisation des filles, de l'âge au moment du mariage, de la pratique contraceptive et de la compréhension de la santé génésique. En particulier, parmi les filles de 10 à 14 ans, celles exposées au programme se sont révélées plus susceptibles, par rapport au groupe témoin, d'être scolarisées au moment de l'enquête de fin d'étude (rapport de probabilités, 3,0) et moins susceptibles d'avoir jamais été mariées $(0,1)$. Toutefois, dans la tranche de 15 à 19 ans, les filles du groupe d'intervention présentent une probabilité élevée d'avoir été mariées avant la fin de l'étude (2,4). Les filles sexuellement expérimentées exposées à l'intervention présentent une probabilité élevée, en fin d'étude, d'avoir pratiqué la contraception $(2,9)$.

Conclusions: Le succès du programme Berhane Hewan, l'une des premières interventions rigoureusement évaluées sur les moyens de différer le mariage en Afrique subsaharienne, laisse entendre que des programmes bien conçus et efficaces dans leur mise en cuvre peuvent différer les mariages les plus précoces jusqu'à l'adolescence plus avancée.

\section{Acknowledgments}

This study was supported by the United Nations Population Fund, the Nike Foundation and the United Nations Foundation. The authors thank their collaborators at the Ethiopia Ministry of Youth and Sport and the Amhara Regional Bureau of Youth and Sport, as well as the officials of the study villages. The authors are also grateful to Helen Amdemikael, Judy Diers, Nicole Haberland, Anrudh Jain, Tekle Ab Mekbib, Mitike Molla, Eva Roca, Hannah Carter-Menn and Tesfahun Wondie for helpful comments on early versions of this article.

Author contact:aerulkar@popcouncil.org 